Annals of Warsaw University of Life Sciences - SGGW

Land Reclamation No 49 (3), 2017: 201-212

(Ann. Warsaw Univ. of Life Sci. - SGGW, Land Reclam. 49 (3), 2017)

\title{
Some geomechanical properties of a biopolymer treated medium sand
}

\author{
MATEUSZ WISZNIEWSKI ${ }^{1}$, ZDZISLAW SKUTNIK ${ }^{2}$, MARCIN BILINIAK ${ }^{2}$, \\ ALI FIRAT ÇABALAR ${ }^{3}$ \\ ${ }^{1}$ Faculty of Civil and Environmental Engineering, Gdansk University of Technology \\ ${ }^{2}$ Faculty of Civil and Environmental Engineering, Warsaw University of Life Sciences - SGGW \\ ${ }^{3}$ Faculty of Engineering, University of Gaziantep
}

\begin{abstract}
Some geomechanical properties of a biopolymer treated medium sand. This paper presents a laboratory assessment of geomechanical properties of sandy soil improved by biopolymer application. Additives (biosubstance) consist of polysaccharides and water. Biosubstance used in the project was xanthan gum, which comes from bacteria Xanthomonas campestris. Triaxial shear compression tests and unconfined compression tests were carried out for investigation purposes. Amount of the biopolymer used in the samples was $0.5,1.0$ and $1.5 \%$, on dry weight basis. It is thought that such application, which is a relatively new technique, could be used as a ground improvement and water seepage barrier, required to strengthen and protect some geotechnical works including foundation, underground structures and waste disposals. The results indicate that behavior of the soil changes rapidly based on the amount of biosubstance. Shear strength parameters have shown a significant increase, which gives a chance for further development and possible applications.
\end{abstract}

Key words: biopolymers, soil strength, biotreated sand, soil improvement

\section{INTRODUCTION}

One of the recent developments in geotechnical engineering is the application of biotechnology to soil improvement. Natural microorganisms and bacteria can be used to produce a biocement for improving mechanical properties of soil by biocementation, bioclogging or even biogas. Biocementation is a process where biocement is applied to improve the shear strength of soil, while bioclogging means reduction of its permeability. Biogas technique is a way of using gas bubbles created by microbial activities to modify and reduce the degree of soil saturation. Application of natural bacteria products into ground improvement methods has brought to life a concept of biogeocivil engineering (Jonkers and Loosdrecht 2010).

Use of biopolymers gives a chance to reduce the generation of hazardous substances currently used for ground improvement design, what could increase public acceptance of the soil treatment. This delivers a product for multiple specific uses, and a long-lived, but ultimately biodegradable, material without the environmental concerns (Goto et al. 2001, Decho 2010). Biopolymers have some important characteristics, such as supreme viscosifying power, high resistance to shear degradation, kind of pseudoplasticity, stability at various ranges of temperature and $\mathrm{pH}$. Thanks to their characteristic chemical structure, biopolymers may have many very useful applications (Khachatoorian et al. 2003). 
Independently from plugging effect, they can bind soil particles, metals and other biopolymers, due to the ability of creating cross-linking networks. Therefore, the biopolymer application into the soils may result in the creation of impervious barriers. The concept and laboratory investigation were already discussed in previous papers (Wiszniewski et al. 2013, Wiszniewski and Cabalar 2014).

Studies showed that the strength parameters of soil can be improved by either inclusion of slime-forming bacteria to the ground to produce a biopolymer inside it, or by direct application of biopolymer from slime-forming bacteria or other commercial products such as guar gum, agar, and sodium alginates to the soil structure.

The use of biopolymers for ground improvement is widely referred in the literature. Several works (Li et al. 1993, Martin et al. 1996, Stewart and Fogler 2001) took into affair biopolymer applications and producing some microorganisms in the soil as plugging agents used for construction of impervious barriers. Cabalar and Canakci (2005), Cabalar et al. (2009) claimed that biopolymers inclusion improved the shear strength of sand and DeJong et al. (2010) wrote that soil stiffness, compressibility, hydraulic conductivity and volumetric response could be arbitrated by means of biological processes. Also, Bouazza et al. (2009) used guar gum, sodium alginate and xanthan gum for inclusion up to $2 \%$ (by dry weight) into a silty sand and found that biopolymers may significantly lower the permeability values. Ivanov and Chu (2008) went through many studies where relatively cheap and ecofriendly biopolymers were adapted to fill pores in granular media and therefore reduced hydraulic conductivity and strengthen the material through cementation. Other researchers (Momeni et al. 1999, Kim et al. 2004) also presented valuable information on biopolymer inclusion.

Khatami and O'Kelly (2013) investigated some mechanical properties of sand treated with agar and starch biopolymers. According to the biopolymer concentration, the unconfined compressive strength of sand treated by biopolymers ranged from 158 to $487 \mathrm{kPa}$. Triaxial compression tests with various confining pressures also revealed that the biopolymers effectively increased cohesion and stiffness of the treated sand. The improvement in characteristics of sand treated with agar and modified starch (biopolymers) has been found to be directly dependent on the amount of agar as the main component and starch as the additive.

The purpose of this work is to investigate geomechnical behavior of a biopolymer treated sand by conducting several laboratory tests. This study shall improve the understanding how precisely how the biopolymers affect soil and their possible applications. While most of the investigations focus on fine and cohesive soils, the present research analyzes the potential use of biopolymer, namely xanthan gum to strengthen non-cohesive soil parameters. For that reason, a triaxial shear test and unconfined compressive strength test were carried out. Applied procedures and test results are explained in detail. 


\section{MATERIAL AND METHODS}

\section{Tested materials}

The materials used for testing are quartz medium sand and xanthan gum. A commercially available biopolymer material was obtained from a local food store in a powder form. Worldwide production of xanthan gum comes out from the bacteria Xanthomonas campestris. Xanthan gum is a polysaccharide that is used for thickening and stabilizing emulsions and suspensions. It is also widely used in the drilling industry to thicken drilling fluids and is very stable under various temperatures and pH (Bouazza et al. 2009). It is very often combined with other rheology modifiers, particularly guar gum to give greatly increased effects. Xanthan gum is not easily degraded by microorganisms (Cadmus et al. 1982). Biopolimer - sand mixture is presented below in Figure 1.

Xanthan gum might be dispersed into hot or cold systems; many grades are available, including some specially designed for easy dispersion. Biopolymer powders have a susceptability weakness to form lumps when added to the water, therefore numbers of dispersion and hy-

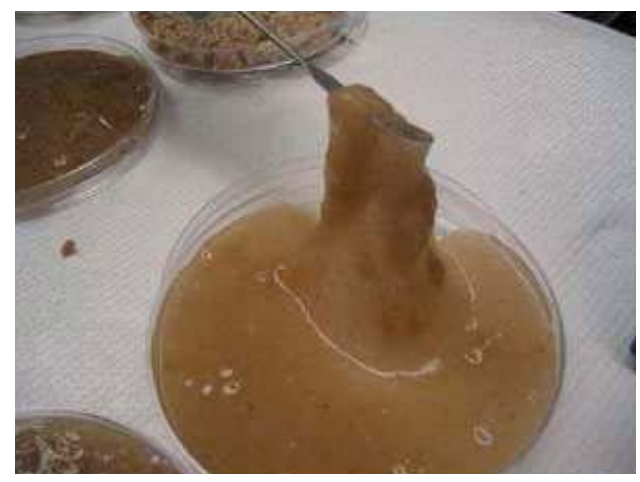

FIGURE 1. Biopolymer - sand viscous mixture (Knox and Petriso 2010) dration methods were developed to overcome this inconvenience. Some of the techniques are (www.silverson.com):

- slow addition of the powder into the vortex in an agitated vessel; once dispersed mixing continues to allow the product to hydrate;

- xanthan gum maybe premixed with other powdered ingredients such as sugars which reduces the formation of agglomerates by separating the particles;

- similarly the gum may be dispersed into non-aqueous phase liquids such as oils, alcohols or glycols; this is then added to the aqueous phase allowing the gum to hydrate.

Soil was obtained from regional sources near Warsaw, Poland. It is a river quartz medium sand. The specific gravity of the grains was found to be $2.68 \mathrm{Mg} / \mathrm{m}^{3}$. A gradation of the sand falling between 1.00 and $0.071 \mathrm{~mm}$ was artificially selected. Soil contains rounded, quartz grains with coefficient of uniformity $C_{u}=1.96$ and coefficient of curvature $C_{c}=0.84$. Each sample has relative density of $45 \%$ that gives $1.66 \mathrm{Mg} / \mathrm{m}^{3}$. The grain size distribution curve of medium sand taken for the investigations is presented in Figure 2, while index properties of this soil in Table 1.

\section{Triaxial loading test}

For investigation, a consolidated drained (CD) test was chosen. Applicable to describe a long term loading response, providing geotechnical parameters designated under the effective stress control. For testing procedures six samples were prepared, each two containing respectively $0.0,0.5$ and $1.5 \%$ of xanthan gum, respectively. Each specimen had a diameter 


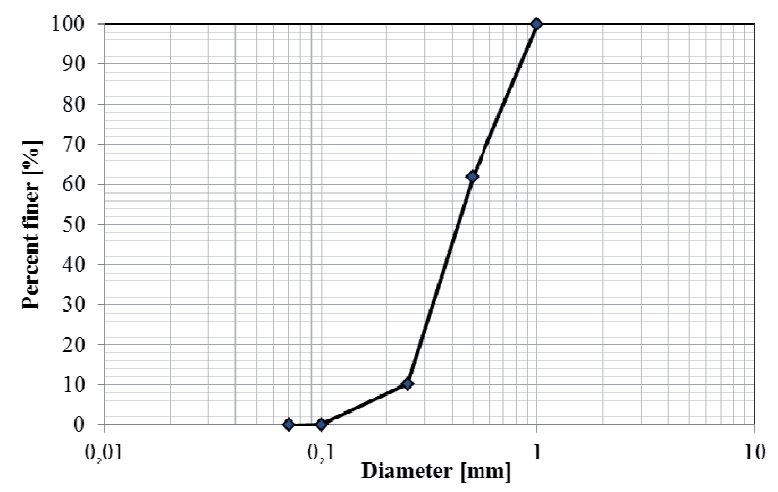

FIGURE 2. Particle size distribution curve

TABLE 1. Index properties of the sand

\begin{tabular}{|c|c|}
\hline Property & Value \\
\hline Minimum void ratio, $e_{\min }$ & 0.45 \\
\hline Maximum void ratio, $e_{\max }$ & 0.70 \\
\hline Relative density, $R_{D}$ & $45 \%$ \\
\hline Uniformity coefficient, $C_{u}$ & 1.96 \\
\hline Curvature coefficient, $C_{C}$ & 0.84 \\
\hline
\end{tabular}

of $70 \mathrm{~mm}$ and height equal to $140 \mathrm{~mm}$, what gives $2: 1$ height-to-diameter ratio. Samples were prepared using a medium quartz sand, at relative density of $45 \%$. Before testing sand was washed and dried in the oven. After bending together soil and biopolymer, $10 \%$ of water (by weight) was added and before placing in the triaxial machine samples were covered by rubber membrane. Following the initial preparation mixtures were saturated, then consolidated and sheared, creating conditions that approximate to those in situ. During the shear stage samples were loaded axially. The saturation process is required to ensure all voids within the specimen are filled with water and that the pore pressure transducer and drainage paths are properly de-aired. To ensure full saturation of the specimen and simulate in-situ pore pressure conditions a back pressure has been applied. Samples were saturated from the bottom up, water pressure was controlled on both sides (bottom and top). Filter-paper side drains were fitted around the triaxial specimens. Both cell pressure and back pressure were increased in increments, allowing time for equalization at each stage. Ratio of change in pore pressure and applied cell pressure change was determined (Skempton's pore pressure parameter $B=0.98$ ), what assured that sample was fully saturated. The consolidation stage was used to put the mixtures into the effective stress required for shearing. It was conducted by increasing the cell pressure while maintaining a constant pore water pressure. The specimen was sheared by applying an axial strain $\left(\varepsilon_{a}\right)$ at a constant rate through upward movement of the load frame platen. Drain condition was ensured by very low shearing rate $-0.01 \mathrm{~mm} / \mathrm{min}(0.429 \%$ / $/ h)$. Water pressure inside the sample was constantly measured, along with back pressure/volume change control (accuracy of $0.03 \mathrm{ml}$ ). The axial deformation of the test specimen was measured using 
a linear displacement transducer (sensitivity of $4.97 \cdot 10^{-3} \mathrm{~mm} / \mathrm{mV}$ ), with the mobilized deviatoric stress measured using a submersible $3 \mathrm{kN}$ load cell (sensitivity of $2.4 \mathrm{mV} / \mathrm{V}$ ) located inside the Perspex pressure cell.

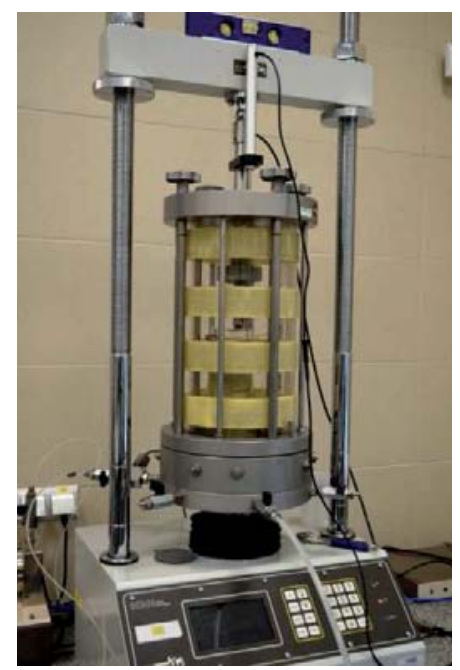

During the test confining pressure was set a constant value, and the deviator stress was increased until the failure criteria represented by the Mohr-Coulomb theory were reached. After the tests were completed, maximum stresses and verti-

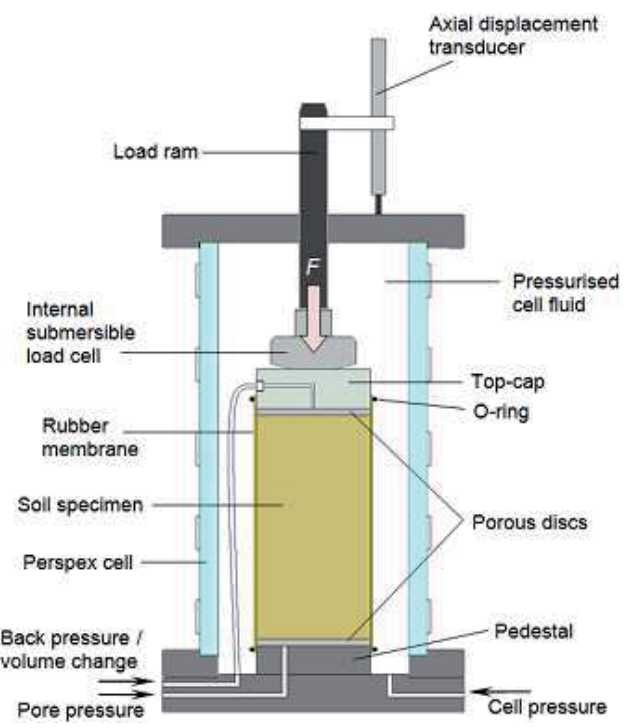

FIGURE 3. General set-up of a soil specimen inside a triaxial cell (www.gdsinstruments.com)

Each mixture was tested in two stages, single sample for each stage. In the first part of investigation, confining pressure $\left(\sigma_{c}\right)$, cell pressure reached the value of $100 \mathrm{kPa}$, while the pore water pressure $(u)$ back pressure, was equal to $50 \mathrm{kPa}$ that gave the minor effective stress $\left(\sigma_{3^{\prime}}\right)$ equal to $50 \mathrm{kPa}$. In the second stage, confining pressure $\left(\sigma_{c}\right)$ was set to be $250 \mathrm{kPa}$, the pore water pressure $u=50$ $\mathrm{kPa}$, in result the minor effective stress $\left(\sigma_{3^{\prime}}\right)$ reached the value of $200 \mathrm{kPa}$. The response of soil during the shear stage was monitored by plotting the deviator stress $(q)$ against the axial strain $\left(\varepsilon_{a}\right)$. The stage was continued until identification of the peak deviator was possible. cal strain determined, shear strength parameters ( $c$ ' - effective cohesion, $\varphi$ ' - effective internal friction angle) could be estimated. Test procedure was based on ASTM D7181 - 11 Method for Consolidated Drained Triaxial Compression Test for Soils. Testing apparatus is presented below in Figure 3.

\section{Unconfined compressive strength tests}

The unconfined compression test is usually used to measure the shearing resistance of cohesive soils. For investigation, specimens were prepared in advance and left for curing - fully saturated. The curing took 1, 3, 7, 14 and 28 days. For each curing period three samples were 
prepared, containing $0.5,1.0$ and $1.5 \%$ of xanthan gum, respectively. After being taken out of the consolidation cell, the specimens were left for drying, in the room temperature, for about 2 months. Biopolymer - sand mixtures due to the hardening process became solid. Cylindrical tubes had a diameter of about $70 \mathrm{~mm}$ and were approximately $70 \mathrm{~mm}$ high. Samples used for testing could be considered as rock material, they appeared to be very stiff. The unconfined compressive strength is probably the most widely applied and quoted rock engineering parameter. Under uniaxial loading conditions the maximum stress that rock sample can sustain is referred as uniaxial compressive strength $\left(\sigma_{c}\right.$ or $\left.q_{u}\right)$. Hard and solid cylindrical samples are shown in Figure 4.

Unconfined compressive strength (UCS) testing was carried out using a digitally-controlled INSTRON testing machine (Fig. 5) with measurement of the applied stress, overall sample height, and strain values.

The UCS testing procedure was based on ASTM D2166 (standard test method for unconfined compressive strength of cohesive soil.

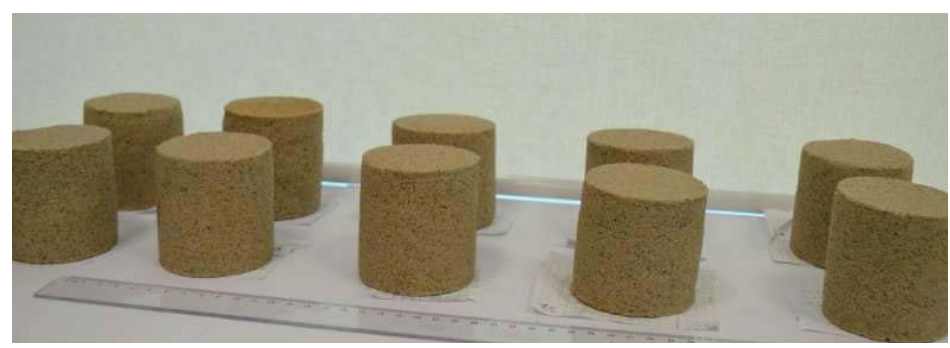

FIGURE 4. Solid sand with xanthan gum samples
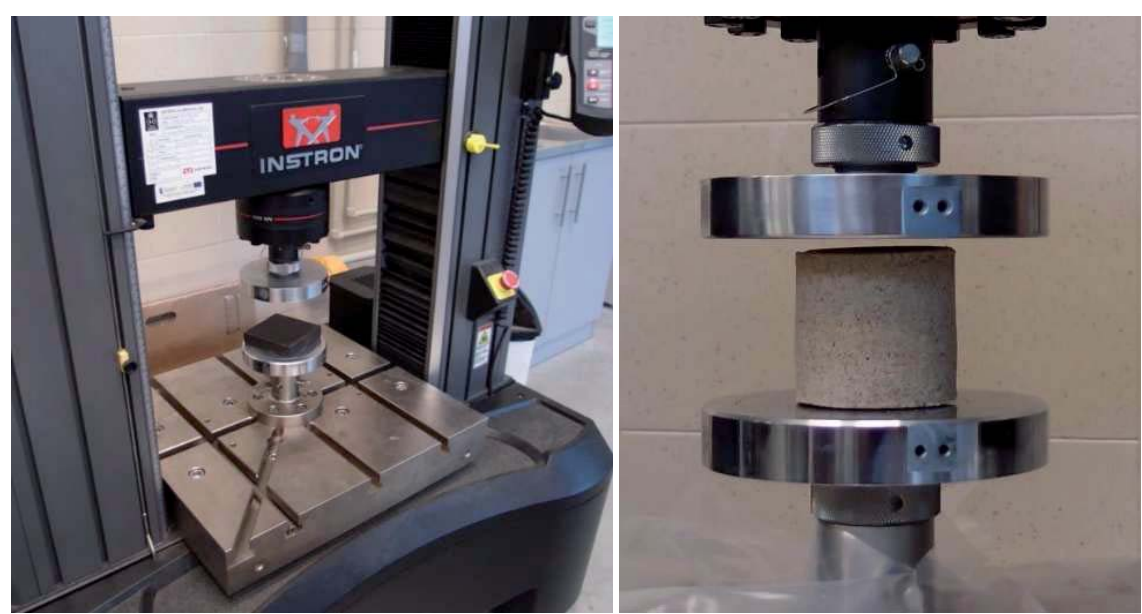

FIGURE 5. INSTRON - mechanical testing system 


\section{RESULTS AND DISCCUSSION}

\section{Triaxial compression test}

The data indicated that higher xanthan gum concentrations produced higher cohesion $(c)$ for the treated sand. For the internal friction angle, value increased for $0.5 \%$ biopolymer addition but decreased for $1.5 \%$, while cohesion for that sample reached nearly $100 \mathrm{kPa}$. Cohesion seems to be most significant in the strength improvement, reaching from 7.14 to $92.95 \mathrm{kPa}$ (for a cohesionless soil - medium sand). The maximum deviatoric stress, mobilized for a given confining pressure, also increased at higher xanthan gum concentrations. This can be easily observed in Figure 6 for the minor principal effective stress $\left(\sigma_{3}{ }^{\prime}\right)$ equal to 50 and equal to $200 \mathrm{kPa}$. Its value for $\sigma_{3}$ ' equal to $50 \mathrm{kPa}$ in the pure sand reached $118.5 \mathrm{kPa}$, while for the mixture containing only $0.5 \%$ of biopolymer it was $198.2 \mathrm{kPa}$ and for $1.5 \%-378.8 \mathrm{kPa}$. That estimates a great potential of the xanthan gum usage in the soil improvement industry, it shows that even a small amount of the biopolymer can significantly change characteristics of the soil.

When the confining effective pressure was equal to $200 \mathrm{kPa}$, the deviatoric stress reached $401.3 \mathrm{kPa}$ for the pure sand and $632.2 \mathrm{kPa}$ for specimens with the biopolymer inclusion for $0.5 \%$ and 617.5 $\mathrm{kPa}$ for $1.5 \%$, respectively. This shows a desired influence of xanthan gum addition on the sample. The calculated data was used for plotting a stress path graphs, which are shown in Figure 7. The stress paths were plotted to determine failure envelopes and the shear strength parameters (effective cohesion - c', and effective friction angle $\left.-\varphi^{\prime}\right)$. Three graphs show the stress growth for each biopolymer - sand mixtures. Two lines represent the stress increment for applied confining pressures $\sigma_{3}$ ' equal to 50 and $200 \mathrm{kPa}$. The specimen treated with xanthan gum sheared along a distinct failure plane at a slightly lower axial strain. It is claimed that since biopolymer gel by itself behaves plastically, increasing its concentration introduces some degree of ductility to the treated soil matrix. Addition of $0.5 \%$ biopolymer had the effect of increasing brittleness. The specimens failed in compression either by bursting into sand clusters, by forming a rough shear plane or an intermediate swelling (increasing the cross section area) state for sand treated with less biopolymer solution. Examples are shown in Figure 8.
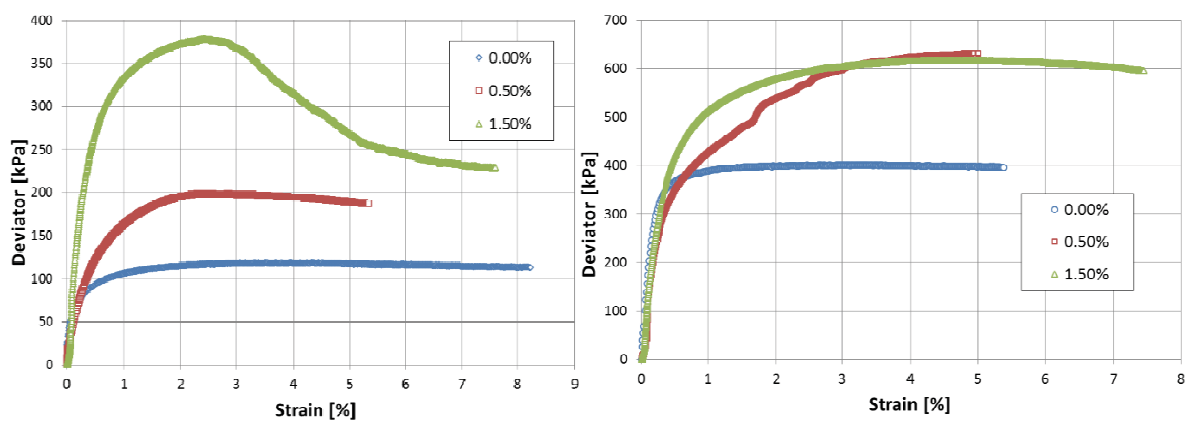

FIGURE 6. Deviatoric stress versus strain for effective confining pressure of $50 \mathrm{kPa}$ (a) and $200 \mathrm{kPa}$ (b) 


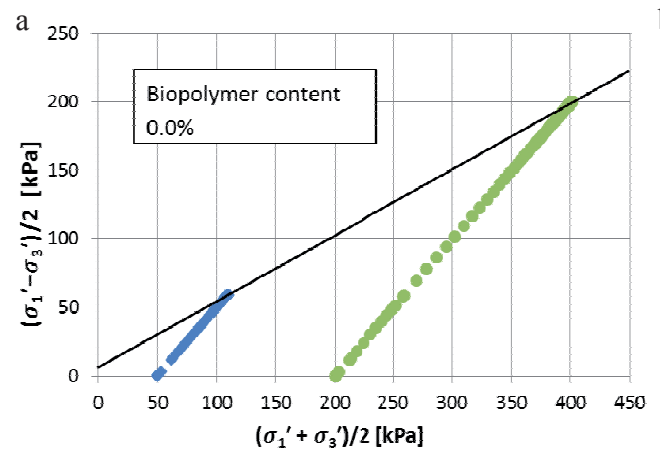

b

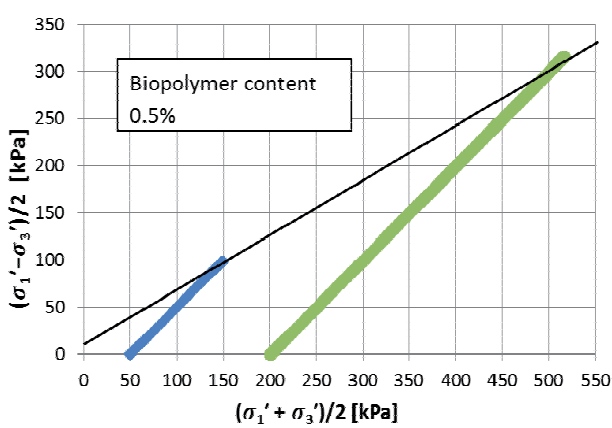

$\mathrm{c}$

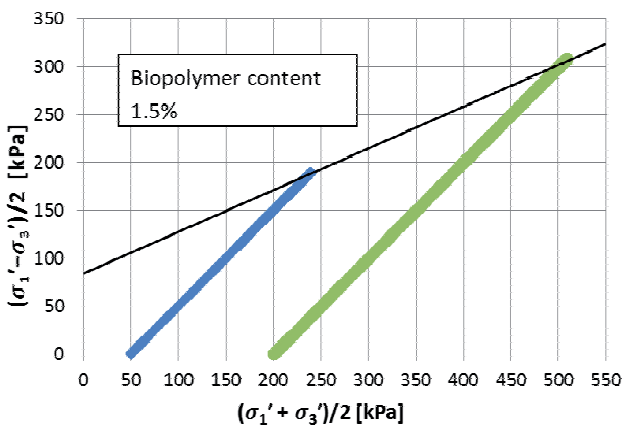

FIGURE 7. Stress paths for specimen with $0.0 \%$ (a), $0.5 \%$ (b) and $1.0 \%$ (c) of the biopolymer
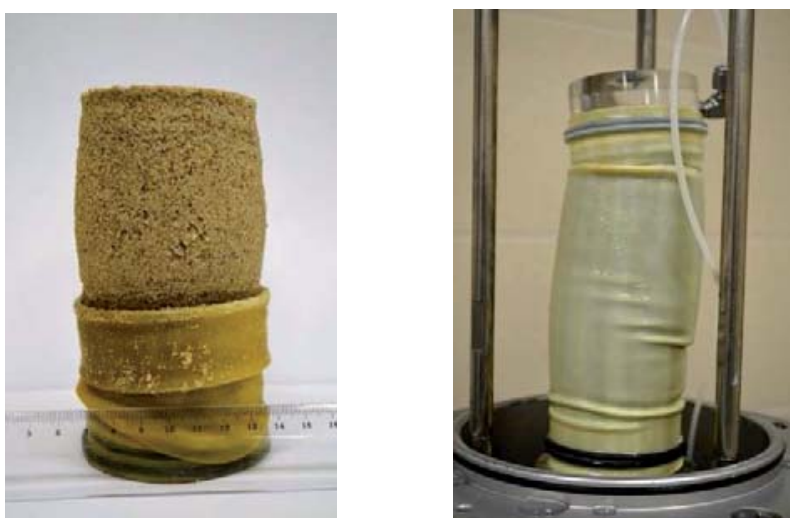

FIGURE 8. Samples after testing

TABLE 2. Shear strength parameters of a biopolymer treated sand

\begin{tabular}{|l|c|c|c|}
\hline \multirow{2}{*}{$\begin{array}{l}\text { Shear } \\
\text { strength } \\
\text { parameters }\end{array}$} & \multicolumn{3}{|c|}{ Biopolymer ratio } \\
\cline { 2 - 4 } & 0.0 & 0.5 & 1.5 \\
\hline$\varphi^{\prime}\left(^{\circ}\right)$ & 29.04 & 36.27 & 26.31 \\
\hline$c^{\prime}(\mathrm{kPa})$ & 7.14 & 13.58 & 92.95 \\
\hline
\end{tabular}


Detailed test results presented in Table 2 indicate that the cohesion intercept was directly proportional to the concentration of xanthan gum, for instance, by twofold for $0.5 \%$ and tenfold for $1.5 \%$. However, the biopolymer inclusion was found to produce a reduction in $\varphi^{\prime}$ from $29^{\circ}$ for the untreated sand to $26^{\circ}$ for sand treated with $1.5 \%$ xanthan gum solution. It is believed that the coating effect of the biopolymer on the grain surfaces has smoothened the micro-scale roughness, hence reducing the interlocking of the sand grains.

\section{Unconfined compressive strength tests}

The research results of experimental work regarding mixtures containing respectively $0.5,1.0$ and $1.5 \%$ of xanthan gum showed that biopolymer inclusion can significantly increase the compressive strength of soil. Depending on the bio- substance concentration, the unconfined compressive strength of mixtures ranged from 1.13 to $2.71 \mathrm{MPa}$. Samples after testing procedure are shown in Figure 9. A high compressive strength means that the sand can withstand more stress under allowable strain or deformation.
Normally it is not possible to conduct unconfined compression test on sandy soil, due to its cohesionless nature. In this case biopolymer addition has changed the soil characteristics. Cementation and binding effect occurred. This shows that even $0.5 \%$ xanthan gum inclusion can significantly enhance the soil mechanical properties. Mixtures containing 1.0 and $1.5 \%$ of biopolymer do not show big differences between each sample, except one specimen, for which the compressive strength reached the value of 2.71 MPa. The UCS test results according to biosubstance concentration are presented in Figure 10. However, it must be noted that all samples were completely dry while testing, the water addition might cause some decomposition of the particles or more elastic behavior. That case needs to be investigated further. As a time effect on the strength of each sample only the curing time was considered (since the moment when mixtures were prepared, sealed and left for conditioning). After that all the samples were left for drying (two months). Little time dependence was observed for sample $0.5 \%$. Compression strength decreased from top value of 1.84 to $1.13 \mathrm{MPa}$ (cur-

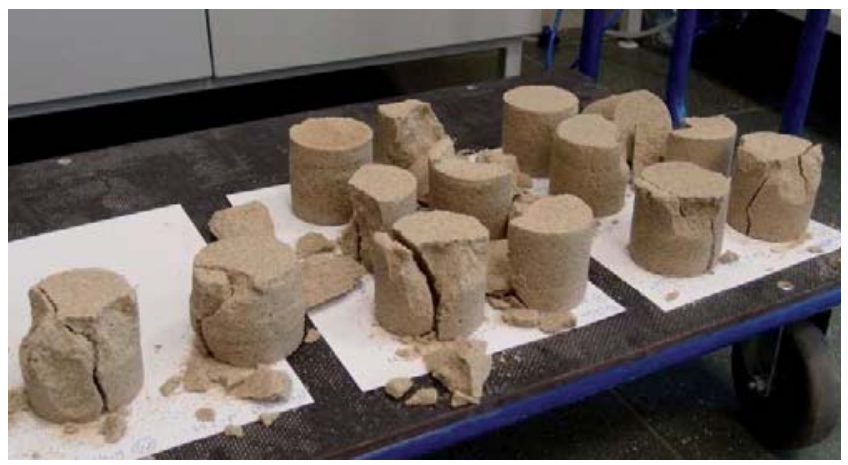

FIGURE 9. Samples after UCS test 

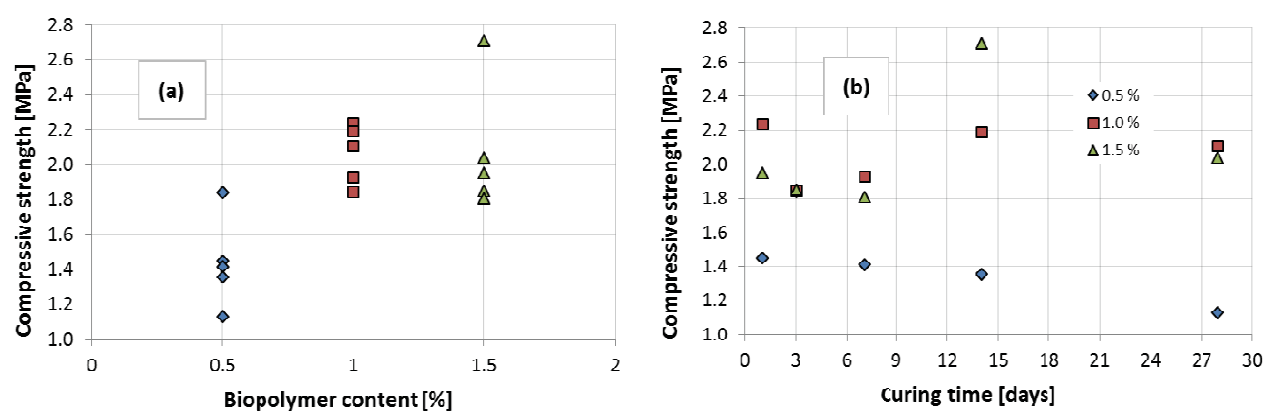

FIGURE 10. Compressive strength of mixtures versus biopolymer content (a) and curing time (b)

ing time of 3 and 28 days, respectively). Compression strength of other samples do not show curing time dependence. All results are presented in Figure 10.

\section{CONCLUSIONS}

The objective of the study was to investigate the behavior of sandy soil and its various mixtures with xanthan gum in the terms of prospective ground improvement application. Laboratory tests such as triaxial compression and unconfined compressive strength tests were conducted. Depending on the findings of the experimental program discussed, the study leads to several conclusions.

The biopolymer can link together the individual soil particles within the soil matrix by cross-linking process. When biosubstance is added to a granular material, it starts behave like a cohesive one. In tested soil samples the cohesion intercept was directly proportional to the concentration of xanthan gum, for instance, by twofold for $0.5 \%$ ratio and tenfold for $1.5 \%$.

The biopolymer inclusion was found to produce a reduction in $\varphi$ from $29^{\circ}$ for the untreated sand to $26^{\circ}$ for sand treated with $1.5 \%$ xanthan gum solution. It is believed that the coating effect of the biopolymer on the grain surfaces has smoothened the micro-scale roughness, hence reducing the interlocking of the sand grains.

Normally it is impossible to conduct unconfined compression test on sandy soil, due to its cohesionless. In this case biopolymer addition has completely changed the soil parameters, cementation and binding effect occurred. Mixtures containing respectively $0.5,1.0$ and $1.5 \%$ of xanthan gum showed that biopolymer inclusion can significantly increase the compression strength of soil. Depending on the biosubstance concentration, the unconfined compressive strength of mixtures ranged from 1.13 to $2.71 \mathrm{MPa}$. It was shown that even $0.5 \%$ xanthan gum inclusion can significantly enhance the soil mechanical properties.

The improvement in performance of sand treated with xanthan gum was found to be directly dependent on the biopolymer concentration. Biopolymers (i.e. xanthan gum) can substantially decrease hydraulic conductivity and improve the strength characteristics of sand without causing environmental toxicity. Biopoly- 
mer treatment occurs to be a promising tool to modify and engineer behavior soils. The eco-friendliness and cost of biopolymers also add to their attractiveness for use in engineering applications.

All tests were conducted in the Water Center Laboratory at the Department of Geotechnical Engineering, Warsaw University of Life Sciences - SGGW in Poland.

\section{REFERENCES}

ASTM D2166. Standard test method for unconfined compressive strength of cohesive soil.

ASTM D7181-11. Standard test method for consolideted drained triaxial compression test for soils.

BOUAZZAA., GATES W.P., RANJITH P.G. 2009: Hydraulic conductivity of biopolymer treated silty sand. Géotechnique 59 (1), 71-72.

CABALAR A.F., CANAKCI H. 2005: Ground Improvement by Bacteria. Proc. Biot Conf. Poromech. Norman, Oklahoma University of Oklahoma.

CABALAR A.F., GARBULEWSKI K., MINIARSKA M. 2009: Some bio-techological considerations in geotechnical engineering. 2nd Int. Conf. New Dev. Soil Mech. Geotech. Eng. Near East University, North Cyprus, Turkey, 518-525.

CADMUS M.C., JACKSON J.K., BURTON K.A., PLATTNER R.D., SLODKI M.E. 1982: Biodegradation of xanthan gum by Bacillus sp. Appl. Enviorn. Microbiol. 44, 5-11.

DECHO A.W. 2010: Overview of biopolymer-induced mineralization: What goes on in biofilms? Ecol. Eng. 36 (2), 137-144.

DeJONG J.T., MORTENSEN B.M., MARTINEZ B.C., NELSON D. C. 2010: Bio-mediated soil improvement. Ecol. Eng. 362, 197-210.

GOTO N., MITAMURA O., TERAI H. 2001: Biodegradation of photosyntheti- cally produced extracellular organic carbon from intertidal benthic algae. $J$. Exper. Mar. Biol. Ecol. 257, 73-86.

IVANOV V., CHU J. 2008: Applications of microorganisms to geotechnical engineering for bioclogging and biocementation of soil in situ. Rev. Environ. Sci. Biotechnol. 7 (2), 139-153.

JONKERS H.M., Van LOOSDRECHT M. 2010: Editorial: BioGeoCivil Engineering. Ecol. Eng. 36, 97-98.

KHACHATOORIAN R., PETRISOR I.G., KWAN C.C., YEN T.F. 2003: Biopolymer plugging effect: laboratory-pressurized pumping flow studies. J. Pet. Sci. Engng 38 (1-2), 13-21.

KHATAMI H.R., O'KELLY B.C. 2013: Improving mechanical properties of sand using biopolymers. ASCE J. Geotech. Geoenviron.Eng. 139. doi101061/(ASCE) GT.1943-5606.0001496.

KIM D., PETRISOR I.G., YEN T.F. 2004: Geopolymerization of biopolymers: a preliminary inquiry. Carbohyd. Polym. 56, 213-217.

KNOX A.S., PETRISOR I.G. 2010: Life Span of Biopolymer Sequestering Agents for Contaminant Removal and Erosion Resistance. In: Biopolymers. InTech.

LI Y., YANG I.C.Y., LEE K-I., YEN T.F. 1993: Subsurface application of Alcaligenes eutrophus for plugging of porous media. Microb. Enhanc. Oil Recov. - Recent $A d v$. Amsterdam, 65-77.

MARTIN G.R., YEN T.F., KARIMI S. 1996: Application of biopolymer technology in silty soil matrices to form impervious barriers. Proc. 7th Australia - New Zealand Geomech. Conf. Adelaide, Australia.

MOMENI D., KAMEL R., MARTIN G.R. YEN T.F. 1999: Potential use of biopolymer grouts for liquefaction mitigation. Phytoremed. Innov. Strat. Spec. Remed. Appl. 5 (6), 175-180.

STEWART T.L., FOGLER H.S. 2001: Biomass plug development and propagation in porous media. Biotechnol. Bioeng. 5, 353-363. 
WISZNIEWSKI M., CABALAR A.F. 2014: Hydraulic conductivity of a biopolymer treated sand, Proc. Geo-Shanghai 2014: New Frontiers in Geotech. Eng. Shanghai, China. GSP 243, 19-27.

WISZNIEWSKI M., SKUTNIK Z., CABALAR A.F. 2013: Laboratory assessment of permeability of sand and biopolymer mixtures. Ann. Warsaw Univ. of Life Sci. - SGGW, Land Reclam. 45 (2): 217-226.

Streszczenie: Niektóre właściwości geomechaniczne piasku średniego traktowanego biopolimerem. W pracy przedstawiono ocenę laboratoryjną właściwości geomechanicznych piasku średniego ulepszonego biopolimerem. Dodatek (biosubstancja) składa się z polisacharydów i wody. Biosubstancją stosowaną w projekcie była guma ksantanowa, pochodzaca $\mathrm{z}$ bakterii Xanthomonas campestris. Przeprowadzono próby wytrzymałościowe w aparacie trójosiowego ściskania oraz próby ściskania jednoosiowego. Ilość biopolimeru stosowanego w próbkach wynosiła $0,5,1,0$ i $1,5 \%$ w przeliczeniu na suchą masę. Uważa się, że takie zastosowanie, będące stosunkowo nową technika, może być wykorzystane jako ulepszenie gruntu i bariera filtracyjna wymagana do wzmocnienia i ochrony niektórych prac geotechnicznych, w tym fundamentów, konstrukcji podziemnych i zabezpieczania składowisk odpadów. Wyniki wskazują, że zachowanie się gruntu ulega zmia- nie w zależności od ilości zastosowanego biopolimeru. Parametry wytrzymałości na ścinanie tak ulepszonego gruntu były na tyle wysokie, że daje to szansę na dalszy rozwój tej technologii i możliwe zastosowanie jej w praktyce.

\section{MS received August 2017}

Authors' addresses:

Mateusz Wiszniewski

Katedra Geotechniki, Geodezji i Budownictwa Morskiego

Wydział Inżynierii Lądowej i Środowiska

Politechnika Gdańska

ul. Narutowicza 11/12, 80-233 Gdańsk

Poland

e-mail: mateusz.wiszniewski@pg.gda.pl

Zdzisław Skutnik, Marcin Biliniak

Katedra Geoinżynierii Wydział Budownictwa i Inżynierii Środowiska SGGW

ul. Nowoursynowska 159, 02-776 Warszawa

Poland

e-mail: zdzislaw_skutnik@sggw.pl

Ali Firat Cabalar

Department of Civil Engineering

University of Gaziantep

27310 Gaziantep

Turkey

e-mail: calabar@gantep.edu.tr 